\title{
Growth, Production and Economic Considerations for Commercial Production of Marketable Sizes of Spotted Babylon, Babylonia areolata, using a Pilot Abandoned Marine Shrimp Hatchery and Recirculating Culture System
}

N. Chaitanawisuti*1 ${ }^{*}$ S. Kritsanapuntu ${ }^{2}$, and W. Santhaweesuk ${ }^{1}$

${ }^{1}$ Aquatic Resources Research Institute Chulalongkorn University

Phya Thai Road, Pathumwan, Bangkok, Thailand 10330

${ }^{2}$ Faculty of Technology and Management Prince of Songkla University Amphur Maueng, Suratani, Thailand 84100

*Corresponding author: nilnajcl@hotmail.com

Keywords: Spotted babylon, Babylonia areolata, commercial production, growth, management, economics, Thailand.

\section{ABSTRACT}

This study was conducted to determine the feasibility for culture of spotted babylon juveniles (Babylonia areolata) to marketable sizes using an abandoned marine shrimp hatchery. It was reconstructed with a large-scale recirculating culture system of $4.0 \times 24.5 \times 0.4$ m concrete rearing ponds. The growth, production and economic analysis for culture of spotted babylon was evaluated. The average growth rates of spotted babylon were $0.94 \mathrm{~g} / \mathrm{mo}$. Feed conversion ratio was 1.8 and the average final survival was $90.5 \%$. At the end of the experiment, the average yield was $148 \mathrm{~kg} /$ pond. The total production for six rearing ponds was estimated at $884 \mathrm{~kg}$. Based on the farm data, stocking data and harvest data used in this study, total cost per 6 month production cycle was $\$ 6,458.40$ (USD). In 2007, at farm gate prices of $\$ 8.60 / \mathrm{kg}$ (USD) resulted in a gross return and net return per production cycle of $\$ 7,575.90$ (USD) 
and $\$ 1,117.50$ (USD), respectively. The benefit cost ratio (BCR) showed a positive profit (1.17) and a payback period of 5.7 production cycles. The present study indicated that the use of an abandoned marine shrimp hatchery reconstructed to include a recirculating culture system was economically attractive for culture of juvenile B. areolata to marketable sizes.

\section{INTRODUCTION}

The spotted babylon, Babylonia areolata Link, 1807, (Figure 1) is now one of the most important marine gastropods for human consumption in Thailand, where the larger-sized specimens (>450 mm) are used for fried and steamed spotted babylon dishes in seafood restaurants. Spotted babylon belongs to Class Gastropoda, Order Neogastropoda, Family Buccinidae. It is abundant and widely inhabits littoral regions in the Gulf of Thailand, especially muddy sand areas not exceeding 10-20 m in depth. The price of spotted babylon ranges from 250 to 500 Baht per kilogram in seafood markets and restaurants, respectively. The spotted babyon fishery, a relatively small-scale fishery, is primarily carried out on natural beds in the Gulf of Thailand. Direct fishery of this species recently developed by means of baited-trap fishing carried out year round. The nature of this fishery is very similar to that of the sand crab (Portunus pelagicus) trap fishery. The spotted babylon fishery has provided an economic supplement to specialized small-scale fisheries for squid and sand crab. However, natural stocks have decreased drastically in recent years because of continuous exploitation in traditional fishing areas, and this has resulted in increased demand and higher prices. The spotted babylon has many biological attributes that make it suitable for profitable aquaculture and is considered a promising new candidate for the industry in Thailand. These attributes include fast growth, high survival rates, low FCR, and relatively simple culture techniques. Large-scale production of juveniles in hatcheries is considered to be technically feasible and these techniques can be transferred to industry. Farming of spotted babylon snail is still in early development in Thailand. The expansion of spotted babylon aquaculture has greatly increased the demand for juveniles. As a consequence, hatcheries need to produce large quantities of high quality eggs and larvae. There has been considerable interest in the commercial culture of spotted babylon in Thailand resulting from this growing demand, an expanding domestic market for seafood, and a catastrophic 
decline in natural spotted babylon populations in the Gulf of Thailand. From an aquaculture point of view, the spotted babylon has many biological attributes, production, and market characteristics necessary for a profitable aquaculture venture and it is considered a promising new candidate for land-based aquaculture in Thailand (Chaitanawisuti and Kritsanapuntu 1999). At present, the successful large-scale culture of spotted babylon juveniles to marketable sizes has been conducted in flow-through seawater systems in concrete / canvas ponds. However, this culture technique has substantial disadvantages for the culture purposes. Basically, the flow-through systems need a high flow rate of high quality seawater, limiting culture areas to those nearby the seashore, bringing seasonal problems related to water quality and pollution, and resulting in high operational costs. The production totals and low economic returns are not high enough to justify commercial operations (Chaitanawisuti, Kritsanapuntu and Natsukari 2002a,b).

Recirculating systems are mechanically sophisticated and biologically complex, and have been used for growing fish and shellfish for more than three decades. Interest in recirculating systems is due to their perceived advantages, including greatly reduced land and water requirements, high degree of environmental control allowing productive-cycle growth at optimum rates, the feasibility of locating culture areas far from the sea, and major improvements in water conservation and reuse (Losordo, Masser and Rakocy 1998; Masser, Rakocy and Losordo 1999). Research on recirculating systems may offer an alternative to pond aquaculture

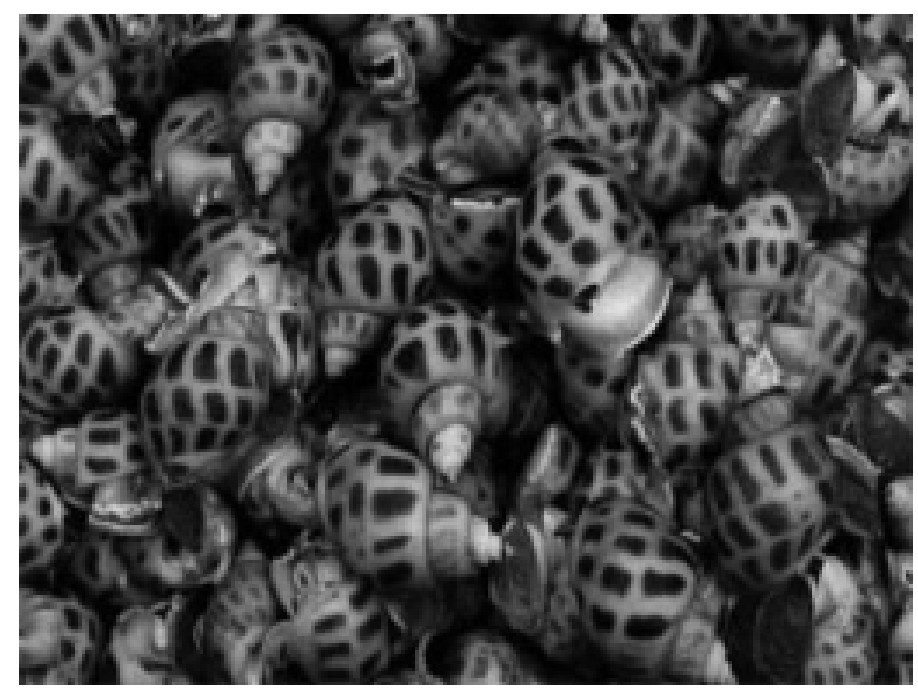

Figure 1. Spotted Babylon, Babylonia areolata Link, from aquaculture in Thailand 
technology and represents a major leap in spotted babylon culture intensification and technology. Much of this progress is necessary to maximize profits by increasing production, lowering costs, and conserving water. This study may provide an opportunity to develop a sustainable aquaculture system for culture of spotted babylon juveniles to marketable sizes in large-scale recirculating culture systems in Thailand. In addition, a lack of economic data on the costs of production and expected economic returns has been a serious constraint to the successful development of spotted babylon aquaculture operations. A financial investment analysis brings together biological factors, production costs, and market price variables to make better decisions regarding culture methods, feasibility, and the overall potential for commercial operation of this enterprise. The objective of this study is to present the growth, production, and economic considerations for commercial production of juvenile spotted babylon, Babylonia areolata, to marketable sizes using an abandoned marine shrimp hatchery and recirculating culture system.

\section{MATERIALS AND METHODS}

\section{Pond design and construction}

This study was conducted at the pilot farm using an abandoned commercial marine shrimp (Penaeus monodon) hatchery at Samutsongkham Province, Thailand, where business operations had ceased seven years previously. The farm consisted of concrete floors and tile roofing in good condition, and was ready for use. The recirculating culture system used in this study consisted of rearing ponds and an integrated water treatment pond. Six concrete rearing ponds, each 98.0 $\mathrm{m}^{2}(4.0 \times 24.5 \mathrm{~m})$ in size $(0.4 \mathrm{~m}$ deep $)$, were constructed. Ponds were arranged in a $2 \times 3$ array with common walls to reduce construction costs. The tank bottom was covered with a $2 \mathrm{~cm}$ layer of coarse sand (0.51.0 mean grain size) to serve as a substrate. A water treatment pond of 3,000 L capacity $(3.0 \times 10.0 \times 1.0 \mathrm{~m})$ was constructed, which contained limestone gravel and oyster shell fragments as biological filtration media, and seaweed (Caulerpa lentillifera) to provide macroalgal absorption. Water flowed from all rearing ponds through the water treatment pond via $2 \mathrm{hp}$ water pumps operating at a constant flow rate of $300 \mathrm{~L} / \mathrm{h}$ for 18 hours daily throughout the experimental period. The water was returned to the rearing ponds via water pumps at the same flow rate. A 3 hp blower was used to provide a high volume of uncontaminated air. Aeration was 
operating daily for 20 hours except during feeding and resting of the blower. Each rearing pond was continuously aerated by twenty air stones at $1.0 \mathrm{~m}$ intervals arranged in a 2 array. Temperature was maintained at $29 \pm 1.5^{\circ} \mathrm{C}$. Water level in the ponds was maintained at $30 \mathrm{~cm}$ in depth and fresh water was added to make up losses due to water evaporation and water loss, maintaining a salinity of 29-30 ppt. The photoperiod was naturally 12-h dark/12-h light.

\section{Seawater preparation and management}

This study used artificial seawater for large-scale production of spotted babylon, in order to reduce costs related to construction of a seawater collection system and pipeline. The farm site was located far from the sea shore and salinity of natural water in the nearby canal was not more than 10 ppt. Prior to the start of culture, the artificial seawater was prepared by using brackish water of $10 \mathrm{ppt}$ as the main component. Thereafter, highly saturated saline seawater obtained from a salt farm was added until culture water reached a salinity of 30 ppt. Seawater in each rearing pond was exchanged at 3 month intervals. When water exchanges were done for each pond, the substrate was cleaned by flushing it with a jet of water and sun dried for $6 \mathrm{~h}$. Thereafter, the rearing ponds were refilled with new artificial seawater as mentioned above. Shell fragments and gravel were also rinsed in water to remove particulate matter, sun dried for $6 \mathrm{~h}$, and returned to the water treatment ponds. Salinity was monitored daily to keep the variation within $\pm 2.0 \mathrm{ppt}$ through the addition of fresh water to correct for any increases in salinity due to water evaporation.

\section{Culture method}

Juvenile $B$. areolata was purchased from a private hatchery. Individuals from the same cohort were sorted by size to prevent possible growth retardation of small babylon when cultured with larger individuals. The spotted babylon juveniles had an average initial body weight of $0.13 \mathrm{~g}$, averaging 7,490 snails per kilogram. Initial stocking density of spotted babylon juveniles was 300 individuals $\mathrm{m}^{-2}$ (29,400 snails per pond). Spotted babylon were fed ad libitum with fresh trash fish once daily at $1000 \mathrm{~h}$. Food was offered to the snails until they stopped feeding. Uneaten food was removed immediately, and air dried for a period of $10 \mathrm{~min}$ before weighing. The amount of food consumed was recorded daily for calculation of the feed conversion ratio (FCR). Size grading of snails in each treatment was not done throughout the culture period. No 
chemical or antibiotic agents were used throughout the entire experiment. To determine growth performance, twenty percent of the snails from each pond were sampled randomly at 30 day intervals, and whole body weight was determined. Whole weight was measured after air drying for a period of $10 \mathrm{~min}$ before weighing. The snails were then returned to the tank. The number of dead individuals were recorded every 30 days. Average body weight gains and growth rates were calculated following the method of Chaitanawisuti and Kritsanapuntu 1999). Mortality, expressed as a percentage of the initial stocking density was calculated from the difference between the number of animals stocked vs. the number harvested. The spotted babylon juveniles were cultured to reach marketable sizes of 120-150 snails/ kg.

\section{Economic evaluation}

The components of the financial analysis were classified as part of the initial investment, annual ownership costs, and annual operating costs as follows:

Initial investment requirements for farm construction were evaluated. The investment requirements included land lease, construction of six $4.0 \mathrm{x}$ $24.5 \times 0.4 \mathrm{~m}$ rearing ponds, one water treatment pond of 3,000 L capacity, two water pumps, one air blower and a PVC pipeline for air and seawater systems.

Fixed costs per production cycle consisted of land, depreciation, and interest on investment. These costs are fixed and incurred in the short run regardless of whether the facilities are operated. Annual depreciation was estimated by the straight-line method based on the expected useful life of each item of equipment. Assets are assumed to have no residual value at the end of their useful life. Six culture ponds and one seawater treatment pond were assumed to have useful life of 5 years. The air blower and seawater pumps were assigned a useful life of 3 years. The life expectancies of equipment were 3 years. Interest rates for capital costs were based on 2007 bank loan rates (3.5\% per year) for this type of business enterprise.

Operating costs per production cycle are incurred upon actual operation of the grow-out unit, and include repairs and maintenance, labor, feed, utilities and interest on operating capital. Costs for purchasing and transportation of spotted babylon juveniles are $\$ 0.01 /$ juvenile (USD). 
Spotted babylon are fed fresh trash fish at a cost of $\$ 0.13 / \mathrm{kg}$ (USD). The costs of repairs and maintenance were estimated based upon the actual expenses for the rearing ponds, water treatment pond, and operating equipment costs. Electricity is used for operating the various pumps and lighting units in the farm. The average charge was $\$ 0.03 /$ kilowatt hour (USD). Labor requirements were based on the particular needs for each production cycle at the proposed farm. One laborer (full-time) was assigned for operation of the farm, at a cost of \$142.90/month (USD). Interest charges for operating capital are based on 2007 bank loan rates (3.5\% per year) for this type of business.

\section{Return analysis}

Net return and return on investment for grow-out production was computed at the selling price of market size spotted babylon at farm gate prices in 2007 , approximately $\$ 8.57 / \mathrm{kg}$ (USD). Gross return was computed from total yield multiplied by the selling price. Net return was calculated from the gross return minus to the total cost per production cycle. Return to capital and management was calculated by subtracting total operation costs from the gross return. Return on investment was estimated by dividing return to capital and management by the initial investment. The payback period (in years) was calculated by investment cost divided by the net return (Fuller, Kelly and Smith 1992).

\section{RESULTS}

\section{Growth and production}

Growth, expressed as body weight and number of snails per kilogram of juvenile $B$. areolata cultured in large-scale recirculating culture systems over a period of 6 months is shown in Figure 2. Snails showed no signs of stress as exhibited by active movement, feeding, and protrusion of the siphon tube throughout the experiment. The mean $( \pm \mathrm{SE})$ weight gains and increases in body weight of spotted babylon were $5.36 \pm 0.42 \mathrm{~g} / \mathrm{snail}$ and $0.94 \pm 0.84 \mathrm{~g} \mathrm{mo}^{-1}$, respectively. The feed conversion ratio (FCR) was 1.8 and the average final survival was $90.5 \%$ (Table 1). At the end of the experiment, the snails reached an average size of $5.6 \mathrm{~g} /$ snail or 147 individuals / $\mathrm{kg}$ after a period of 6 months. The average yield of spotted babylon was $148 \mathrm{~kg} /$ pond and the overall production of the six rearing ponds was $884 \mathrm{~kg}$ (Table 1). 

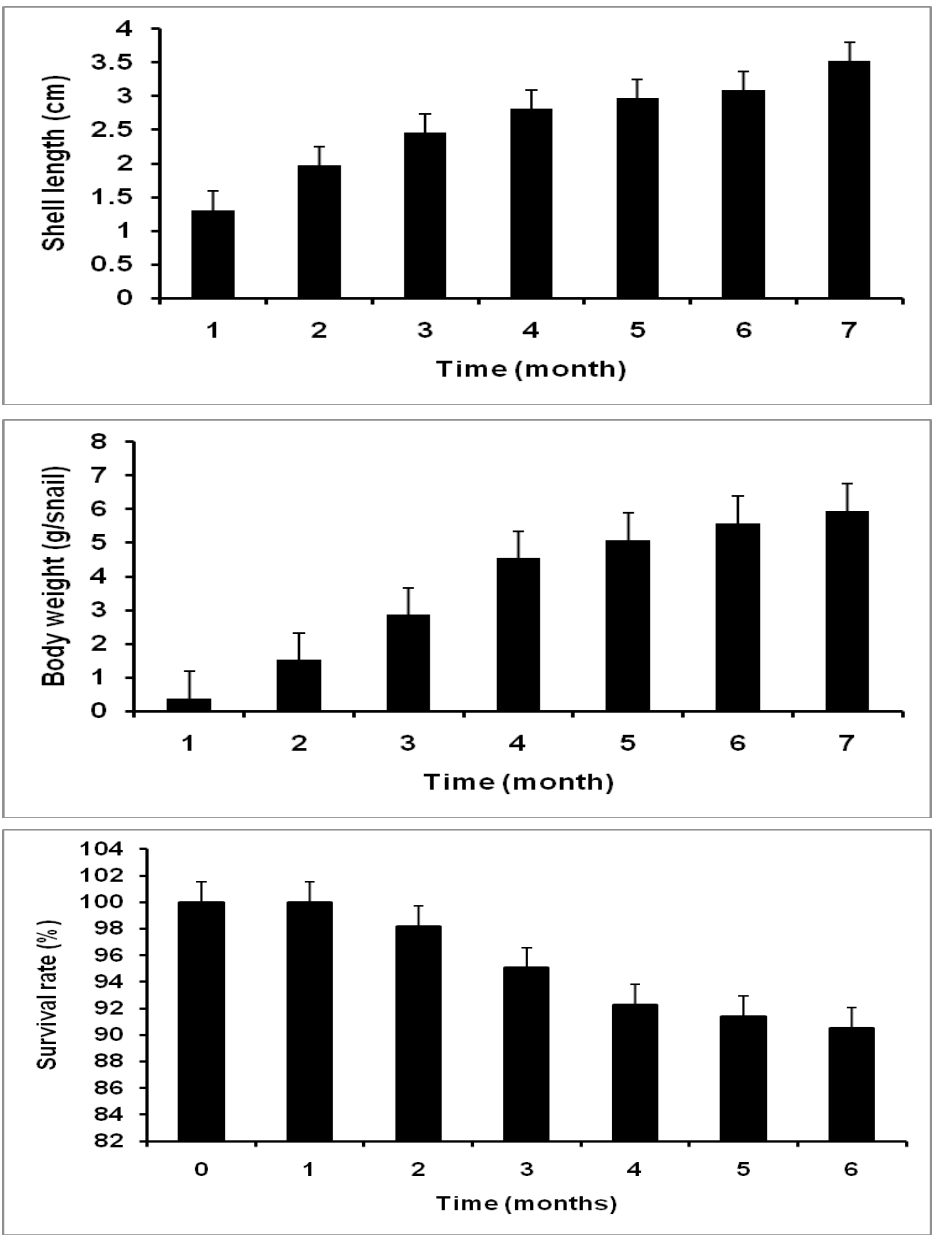

Figure 2. Growth in shell length (upper), body weight (middle), and survival (bottom) of juvenile Babylonia areolata cultured in a large-scale recirculating culture system.

\section{Water quality}

Seawater monitoring indicated that water temperature, conductivity, salinity, $\mathrm{pH}$, and dissolved oxygen changed gradually with no significant differences recorded throughout the experimental period $(P>0.05)$ but there were significant differences $(P<0.05)$ in alkalinity $(50.5-120.0 \mathrm{mg} / \mathrm{L})$ total suspended solid (25.3-74.5 mg/L), ammonia-nitrogen (0.002-0.950 $\mathrm{mg} / \mathrm{L})$. nitrite-nitrogen $(0.007-0.225 \mathrm{mg} / \mathrm{L})$, nitrate-nitrogen $(0.050-28.644$ $\mathrm{mg} / \mathrm{L}$ ) and phosphate-phosphorus (0.053-1.110 mg/L) (Table 2).

\section{Financial analysis}

Farm data (pond sizes and total pond area), stocking data (initial weight, stocking density), and harvest data (duration of culture, weight at harvest, 


\begin{tabular}{|l|l|}
\hline Farm data & \\
\hline Rearing pond size $(\mathrm{m})$ & $4.0 \times 24.5 \times 0.4$ \\
\hline Pond bottom area $\left(\mathrm{m}^{2}\right)$ & 98.0 \\
\hline Number of rearing ponds & 6 \\
\hline Total culture areas $\left(\mathrm{m}^{2}\right)$ & 588.0 \\
\hline Water treatment pond (m) & $3.0 \times 10.0 \times 1.0$ \\
\hline Grow out data & 0.13 \\
\hline Initial weight (g/snail) & 7,490 \\
\hline Initial sizes (snails/kg) & 300 \\
\hline Stocking density (no per $\left.\mathrm{m}^{2}\right)$ & 29,400 \\
\hline $\begin{array}{l}\text { Number of snails per pond } \\
\text { (individuals) }\end{array}$ & 176,400 \\
\hline Total snails per crop (individuals) & 0.01 \\
\hline Juvenile cost (\$US/individual) & 0.13 \\
\hline Duration of grow-out (mo/crop) & 3,240 \\
\hline Feed cost (\$US/kg) & 0.3 \\
\hline Harvest data & \\
\hline Final weight (g/snail) & 5.4 \\
\hline Final sizes (individual/kg) & 147 \\
\hline Growth rate (g/month) & 0.9 \\
\hline Final survival (\%) & 90.5 \\
\hline Feed conversion ratio (FCR) & 1.8 \\
\hline Average yield per pond (kg) & 148 \\
\hline
\end{tabular}

Table 1. Actual data used for culture of juvenile Babylonia areolata in a large-scale recirculating culture system.

Note: All cost estimations based on Thai Baht have been converted to US\$, using 2007 currency exchange rates.

final survival, feed conversion ratio, and yield) are based on the actual data from the pilot farm. Parameters used for the economic analysis for culture of spotted babylon in large-scale recirculating culture system are summarized in Tables 3 through 8 . The total investment required for construction of a culture area of $588 \mathrm{~m}^{2}$ was estimated to be $\$ 6,371.40$ (USD). Construction of rearing ponds and the seawater treatment pond was the largest cost component of the farm. These two components represented $77.1 \%$ of the total investment requirements for production of spotted babylon in this large-scale recirculating culture system (Table 3). Fixed cost per production cycle was estimated to be $\$ 1,004.90$ (USD). The major fixed cost items were depreciation, repair and maintenance, and interest on investment, accounting for $73.0 \%, 15.8 \%$, and $11.0 \%$ of total fixed costs, respectively (Tables 4 and 5). Operating costs per production 
Table 2. Water quality of seawater in recirculating and flow-through systems for culture of spotted babylon (Babylonia areolata).

\begin{tabular}{|c|c|c|}
\hline Parameters & $\begin{array}{c}\text { Recirculating } \\
\text { system }\end{array}$ & $\begin{array}{c}\text { Flow-through } \\
\text { system }\end{array}$ \\
\hline Water temperature $\left({ }^{\circ} \mathrm{C}\right)$ & $27.3 \pm 0.5^{\mathrm{a}}$ & $27.3 \pm 0.5^{\mathrm{a}}$ \\
\hline Salinity (ppt) & $\begin{array}{l}30.9 \pm 0.5^{\mathrm{a}} \\
(30.3-32.0)\end{array}$ & $\begin{array}{l}30.8 \pm 0.5^{\mathrm{a}} \\
(29.8-31.9)\end{array}$ \\
\hline $\mathrm{pH}$ & $\begin{array}{l}7.78 \pm 0.16^{\mathrm{a}} \\
(7.59-8.30)\end{array}$ & $\begin{array}{l}7.78 \pm 0.16^{\mathrm{a}} \\
(7.63-8.30)\end{array}$ \\
\hline $\begin{array}{l}\text { Dissolved Oxygen } \\
(\mathrm{mg} / \mathrm{L})\end{array}$ & $\begin{array}{l}6.1 \pm 0.6^{\mathrm{a}} \\
(5.3-7.4)\end{array}$ & $\begin{array}{l}6.2 \pm 0.6^{\mathrm{a}} \\
(5.2-7.5)\end{array}$ \\
\hline Alkalinity (mg/L) & $\begin{array}{l}72.5 \pm 16.4^{\mathrm{ac}} \\
(52.0-110.0)\end{array}$ & $\begin{array}{l}112.7 \pm 12.9^{\mathrm{ac}} \\
(110.5-120.0)\end{array}$ \\
\hline $\begin{array}{l}\text { Ammonia-nitrogen } \\
(\mathrm{mg}-\mathrm{N} / \mathrm{L})\end{array}$ & $\begin{array}{l}1.36 \pm 0.228^{\mathrm{a}} \\
(0.006-0.950)\end{array}$ & $\begin{array}{l}0.062 \pm 0.063^{b} \\
(0.005-0.246)\end{array}$ \\
\hline Nitrite-nitrogen (mg-N/L) & $\begin{array}{l}0.062 \pm 0.045^{\mathrm{a}} \\
(0.007-0.225)\end{array}$ & $\begin{array}{c}0.046 \pm 0.028^{b} \\
(0.007-0.118)\end{array}$ \\
\hline $\begin{array}{l}\text { Nitrate-nitrogen } \\
(\mathrm{mg}-\mathrm{N} / \mathrm{L})\end{array}$ & $\begin{array}{l}10.661 \pm 6.896^{\mathrm{a}} \\
(0.050-19.097)\end{array}$ & $\begin{array}{l}12.038 \pm 8.418^{\mathrm{b}} \\
(0.050-28.644)\end{array}$ \\
\hline $\begin{array}{l}\text { Total dissolved nitrogen } \\
(\mathrm{mg}-\mathrm{N} / \mathrm{L})\end{array}$ & $\begin{array}{l}12.275 \pm 6.723^{\mathrm{a}} \\
(2.019-22.109)\end{array}$ & $\begin{array}{l}13.638 \pm 8.032^{\mathrm{b}} \\
(2.019-29.368)\end{array}$ \\
\hline $\begin{array}{l}\text { Phosphate - phosphorus } \\
\text { (mg-P/L) }\end{array}$ & $\begin{array}{c}0.543 \pm 0.316^{\mathrm{b}} \\
(0.053-0.997)\end{array}$ & $\begin{array}{l}0.450 \pm 0.265^{\mathrm{c}} \\
(0.053-0.785)\end{array}$ \\
\hline $\begin{array}{l}\text { Total dissolved } \\
\text { phosphorus (mg-P/L) }\end{array}$ & $\begin{array}{c}0.749 \pm 0.309^{\mathrm{be}} \\
(0.224-1.289)\end{array}$ & $\begin{array}{l}0.631 \pm 0.229^{c} \\
(0.224-0.949)\end{array}$ \\
\hline
\end{tabular}

Note: Values are mean $\pm S D$, numbers in parentheses are minimum and maximum.

cycle were estimated to be $\$ 5,453.50$ (USD). The four major operating cost items were purchasing of juveniles, feed, labor, and electricity, representing $41.5 \%, 18.6 \%, 15.7 \%$, and $12.6 \%$ of total operating costs, respectively (Table 6). Total costs per production cycle were estimated to be $\$ 6,458.40$ (USD). The top five major total cost items were purchasing of juveniles, feed, labor, depreciation, and electricity, representing $35.1 \%$, $15.8 \%, 13.3 \%, 11.4 \%$, and $10.6 \%$ of total costs, respectively (Table 7). The cost of producing spotted babylon to marketable sizes in this farm design was $\$ 7.30 / \mathrm{kg}$ (USD). 


\begin{tabular}{rlcc}
\cline { 2 - 4 } Table 3. Estimated & \multicolumn{1}{c}{ Items } & US\$ & $\mathbf{\%}$ \\
\cline { 2 - 4 } investment & Six rearing concrete ponds $(4.0 \times 24.5 \times 0.4 \mathrm{~m})$ & $4,285.7$ & 67.3 \\
requirements for & One water treatment pond $(3.0 \times 10.0 \times 1.0 \mathrm{~m})$ & 628.6 & 9.9 \\
culture of juvenile & Two water pumps & 400.0 & 6.3 \\
Babylonia areolata & One air blowers & 342.8 & 5.4 \\
in large-scale & Operating equipment & 285.7 & 4.5 \\
recirculating & Miscellaneous & 428.6 & 6.7 \\
culture system. & \multicolumn{1}{c}{ Total investment } & $6,371.4$ & 100 \\
\cline { 2 - 4 } & &
\end{tabular}

Note: All cost estimations based on Thai Baht have been converted to US\$.

Table 4. Estimated depreciation, interest charges, and repair and maintenance costs for culture of juvenile Babylonia areolata in a large-scale recirculating culture system.

\begin{tabular}{lcccccc}
\hline \multicolumn{1}{c}{ Items } & $\begin{array}{c}\text { No. } \\
\text { of } \\
\text { units }\end{array}$ & $\begin{array}{c}\text { Total } \\
\text { cost of } \\
\text { items } \\
\text { (US\$) }\end{array}$ & $\begin{array}{c}\text { Estimated } \\
\text { Life } \\
\text { (year) }\end{array}$ & $\begin{array}{c}\text { Annual } \\
\text { depreciation } \\
\text { (US\$) }\end{array}$ & $\begin{array}{c}\text { Annual } \\
\text { interest } \\
\text { charges }^{1} \\
\text { (US\$) }\end{array}$ & $\begin{array}{c}\text { Annual } \\
\text { repairs / } \\
\text { maintenance } \\
\text { (US\$) }\end{array}$ \\
\hline Rearing ponds & 6 & $4,285.7$ & 5 & 857.1 & 149.9 & 214.3 \\
Water treatment pond & 1 & 628.6 & 5 & 125.7 & 22.0 & 31.4 \\
Seawater pumps & 2 & 400.0 & 3 & 133.3 & 14.0 & 20.0 \\
Air blowers & 1 & 342.8 & 3 & 114.3 & 11.9 & 17.1 \\
Operating equipment & 1 & 285.7 & 3 & 95.2 & 9.9 & 14.3 \\
Miscellaneous & 1 & 428.6 & 3 & 142.9 & 15.0 & 21.4 \\
Total cost per year & & $6,371.4$ & 3 & $1,468.5$ & 222.7 & 318.5 \\
\hline
\end{tabular}

Note: All cost estimations based on Thai Baht have been converted to US\$, ${ }^{1}$ Annual interest charges for all items are estimated to be $3.5 \%,{ }^{2}$ Annual repairs Imaintenance for all items are estimated to be $5 \%$.

\begin{tabular}{rlcc}
\hline \multirow{2}{*}{\begin{tabular}{r} 
Table 5. Estimated \\
\cline { 2 - 4 } fixed costs for culture
\end{tabular}} & \multicolumn{1}{c}{ Items } & US\$ & \% \\
\cline { 2 - 4 } of juvenile Babylonia & Annual depreciation & $1,468.5$ & 73.0 \\
areolata in large-scale & Annual interest charges & 222.7 & 11.1 \\
recirculating & Annual repairs /maintenance & 318.5 & 15.9 \\
\cline { 2 - 4 } culture system. & Total fixed cost per annum & $2,009.7$ & 100 \\
& Total fixed cost per production cycle & $1,004.9$ & \\
& Fixed cost per $\mathrm{kg}^{2}$ & 1.14 & \\
\cline { 2 - 4 } & &
\end{tabular}

Note: All cost estimations based on Thai Baht have been converted to US\$, ${ }^{1}$ One production cycle was 6 months, ${ }^{2}$ Yield per production cycle was $884 \mathrm{~kg}$. 


\begin{tabular}{|c|c|c|c|}
\hline \multirow{4}{*}{$\begin{array}{l}\text { Table 6. Estimated } \\
\text { operating costs per } \\
\text { production cycle for } \\
\text { culture of juvenile }\end{array}$} & Items & US\$ & $\%$ \\
\hline & Purchase of juveniles ${ }^{1}$ & $2,268.0$ & 41.6 \\
\hline & Purchase of highly saturated seawater ${ }^{2}$ & 154.3 & 2.8 \\
\hline & Electricity for water pump and air blowers & 685.7 & 12.6 \\
\hline \multirow{6}{*}{$\begin{array}{r}\text { Babylonia areolata in } \\
\text { a large-scale } \\
\text { recirculating } \\
\text { culture system. }\end{array}$} & Feed $^{3}$ & $1,018.3$ & 18.7 \\
\hline & Hired labor (1 full time) & 857.1 & 15.7 \\
\hline & Repairs and maintenance & 285.7 & 5.2 \\
\hline & Interest on operating $\cos t^{4}$ & 184.4 & 3.4 \\
\hline & Operating cost per production cycle 5 & $5,453.5$ & 100 \\
\hline & Operating cost per $\mathrm{kg}^{6}$ & 6.17 & \\
\hline
\end{tabular}

Notes: All cost estimations based on Thai Baht have been converted to US\$, ${ }^{1}$ Selling price of juvenile spotted babylon was \$US 0.01/individual, ${ }^{2}$ Highly saturated seawater was $\$ U S 3.7 /$ ton, ${ }^{3}$ Feed price was $\$ U S 0.13 / \mathrm{kg}$, and total feed consumed of 32,400 kg, ${ }^{4}$ Interest charges are based on 2007 bank loan rates $\left(3.5 \%\right.$ per year), ${ }^{5}$ One production cycle was 6 months, ${ }^{6}$ Yield per production cycle was $884 \mathrm{~kg}$.

\begin{tabular}{rlll}
\hline Table 7. Estimated & \multicolumn{1}{c}{ Items } & US\$ & \% \\
\cline { 2 - 4 } total cost per & Fixed costs per production cycle ${ }^{1}$ & $\mathbf{1 , 0 0 4 . 9}$ & $\mathbf{1 5 . 6}$ \\
production cycle for & Depreciation & 734.3 & 11.4 \\
culture of juvenile & Interest & 111.4 & 1.7 \\
Babylonia areolata & Repairs and maintenance & 159.3 & 2.5 \\
in a large-scale & Operating costs per production cycle & $\mathbf{5 , 4 5 3 . 5}$ & $\mathbf{8 4 . 4}$ \\
recirculating & Purchasing for juveniles & $2,268.0$ & 35.1 \\
culture system. & Purchasing for highly saturated seawater & 154.3 & 2.4 \\
& Electricity for water pump and air blowers & 685.7 & 10.6 \\
& Feed & $1,018.3$ & 15.8 \\
& Labor (1 full time) & 857.1 & 13.3 \\
& Repairs and maintenance & 285.7 & 4.4 \\
& Interests on operating cost & 184.4 & 2.8 \\
\cline { 2 - 4 } & Total cost per production cycle & $6,458.4$ & 100 \\
& Total cost per kg & 7.3 & \\
\cline { 2 - 4 } & & &
\end{tabular}

Notes: All cost estimations based on Thai Baht have been converted to US\$, ${ }^{1}$ One production cycle was 6 months, ${ }^{2}$ Yield per production cycle was $884 \mathrm{~kg}$. 


\section{Economic returns}

The enterprise budgets based on the 2007 farm gate price of spotted babylon -- $\$ 8.60 / \mathrm{kg}$ (USD), resulted in a gross return and net return per production cycle of $\$ 7,575.90$ (USD) and $\$ 1,117.50$ (USD), respectively. Return to capital and management and return on investment were $\$ 2,122.40$ (USD) and 0.3, respectively. The break-even production and break-even price were estimated to be $418.7 \mathrm{~kg}$ and $\$ 3,588.90$ (USD), respectively. Benefit cost ratio (BCR) showed a positive profit (1.17) and a payback period of 5.7 production cycles (Table 8).

\begin{tabular}{|c|c|c|}
\hline \multirow{3}{*}{$\begin{array}{r}\text { Table 8. Economic } \\
\text { analysis for culture of } \\
\text { juvenile Babylonia areolata }\end{array}$} & \multicolumn{2}{|l|}{ Yield } \\
\hline & Yield per production cycle $(\mathrm{kg})$ & 884 \\
\hline & Costs & \\
\hline recirculating & Investment requirements $^{1}$ & $6,371.4$ \\
\hline culture system. & Fixed costs (per production cycle) & $1,004.9$ \\
\hline & Operating costs (per production cycle) & $5,453.5$ \\
\hline & Total cost (per production cycle) & $6,458.4$ \\
\hline & Returns & \\
\hline & Gross return ${ }^{2}$ (per production cycle) & $7,575.90$ \\
\hline & Net returns (per production cycle) & $1,117.50$ \\
\hline & Return to capital and management ${ }^{4}$ & $2,122.40$ \\
\hline & Return on investment ${ }^{5}$ & 0.33 \\
\hline & Net returns (per kg) & 1.3 \\
\hline & Benefit-cost ratio (BCR) & 1.17 \\
\hline & Break-even production $(\mathrm{kg})$ & 418.7 \\
\hline & Break-even price & $3,588.90$ \\
\hline & Payback period (production cycle) ${ }^{3}$ & 5.7 \\
\hline
\end{tabular}

Notes: All cost estimations based on Thai Baht have been converted to US\$, ${ }^{1}$ Whole operation of 6 rearing ponds of $4.0 \times 24.5 \times 0.4 \mathrm{~m}$ each, ${ }^{2}$ Market price for spotted babylon in 2007 (\$8.57 per $\mathrm{kg}$ ), ${ }^{3}$ One production cycle was 6 months, ${ }^{4}$ Return to capital and management $=$ Gross return - Total operation cost, ${ }^{5}$ Return on investment $=$ Return to capital and management / initial investment. 


\section{DISCUSSION}

In this study, culture of spotted babylon juveniles (Babylonia areolata) to marketable sizes using a pilot abandoned marine shrimp hatchery reconstructed with large-scale recirculating system showed good results for growth, production, and economic returns. In this study, the average growth rates in body weight of spotted babylon were $0.94 \mathrm{~g} \mathrm{mo}^{-1}$ with final body weights are $5.66 \mathrm{~g}$. Feed conversion ratio and final survival was 2.11 and $96.79 \%$, respectively. At the end of the experiment, the snails reached an average size of 177 individuals / $\mathrm{kg}$, and the average yield of spotted babylon was $148 \mathrm{~kg}$ / pond. Total production of six rearing ponds was $884 \mathrm{~kg}$. In contrast to those raised in flow-through systems, Chaitanawisuti and Kritsanapuntu (1999) reported that average monthly growth rates of spotted babylon in a flow-through culture system consisting of concrete / canvas ponds was $1.4 \mathrm{~g} / \mathrm{mo}$. FCR and final survival were 1.6 and $95.8 \%$, respectively. However, growth of the spotted babylon in the recirculating system was slightly slower than for those individuals raised in the flow-through system. The major issues leading to slow growth of spotted babylon in the recirculating system may be mineral depletion of the seawater used, particularly a shortage of calcium needed for shell formation, which caused shell abnormalities and slow growth. This problem was mainly characterized by observation of the following external shell morphology: shell color with dark brown spots gradually changed to pale brown, and the outer shell layer was partially removed (Figure 3). Shell abnormalities and slow growth may be due to insufficient calcium and other minerals in the recirculating system, because depletion of these elements required for shell building resulted in a loss of calcium from the shell to the outside medium to achieved equilibrium concentration of calcium between the blood and outside medium. Addition of these elements to the diet cannot compensate for their absence in the growing water, due to the low bioavailability of these feed additives for use in shell building. Calta (2000) reported that a number of aquatic mollusks are able to absorb most of their calcium directly from the surrounding water. Calcium is a very important element for fish and shellfish because it is necessary for a variety of functions such as bone and scale growth, shell building, muscle contraction, transmission of nerve impulses, intercellular signalling, hormone secretion, and buffering of osmotic and ionic changes. Hincks and Mackie (1997) reported that maximum growth of zebra mussel (Dreissena polymorpha) 

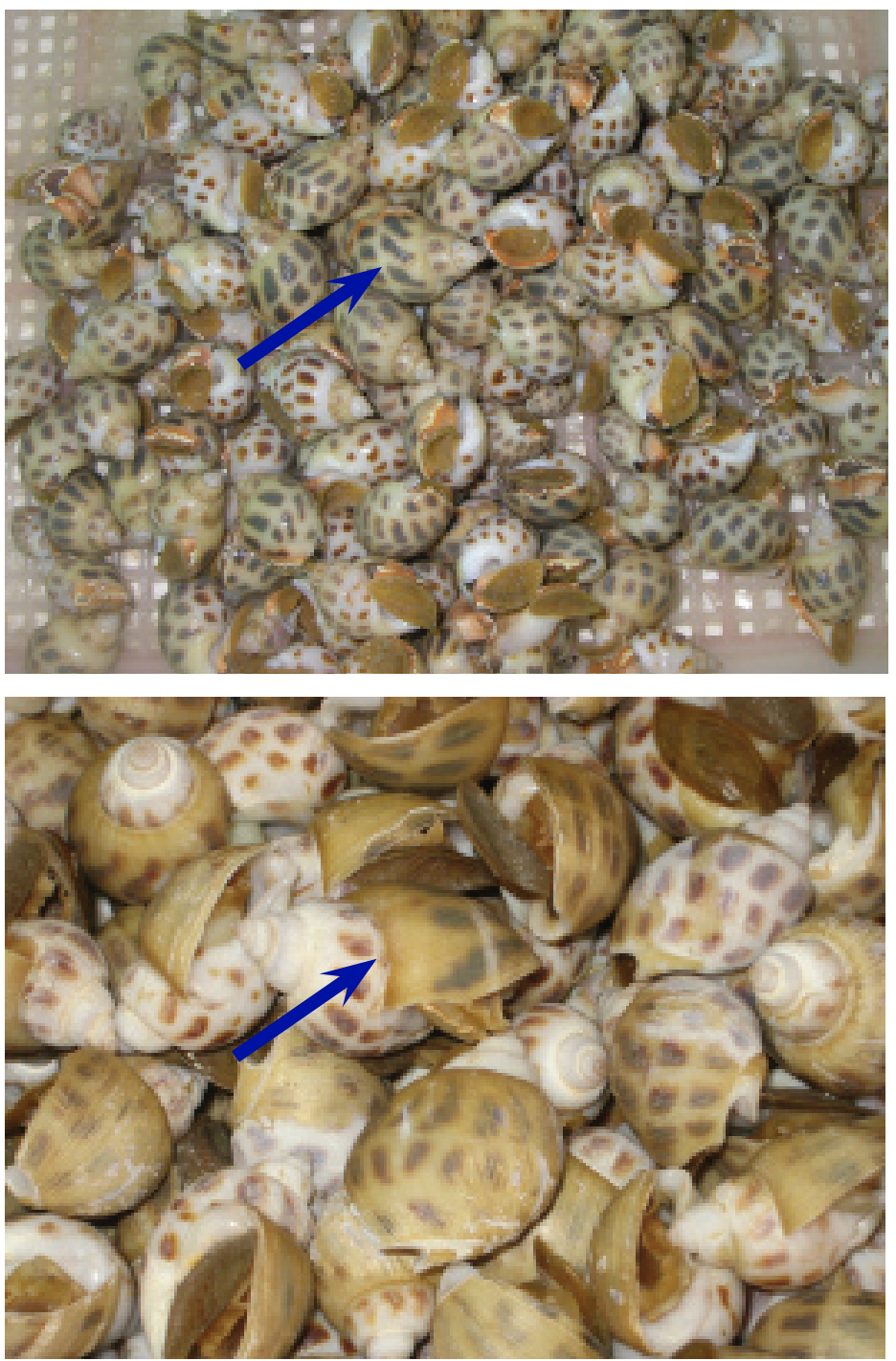

Figure 3. Normal shell (above) and shell abnormality (below) in Babylonia areolata, characterized by change in shell color from dark brown spots to pale brown, and the partial removal of the outer shell layer. 
occurred at calcium levels of $32 \mathrm{mg} \mathrm{Ca} / \mathrm{L}$, alkalinity of $65 \mathrm{mg} \mathrm{CaCO}_{3}$ $\mathrm{L}^{-1}$, and total hardness of $100 \mathrm{mg} \mathrm{CaCO}_{3} / \mathrm{L}$. There was negative growth at calcium levels of less than $31 \mathrm{mg} \mathrm{CaCO}_{3} / \mathrm{L}$, and positive growth of juvenile zebra mussels only occurred at a $\mathrm{pH}$ greater than 8.3. They also stated that mollusk shells are composed primarily of crystalline $\mathrm{CaCO}_{3}$ (96.3\% $\mathrm{CaCO}_{3}$ and $0.34 \% \mathrm{MgCO}_{3}$ in zebra mussel) bound together in an organic matrix. Most of the calcium deposited in the shell (80\%) is actively taken up from the seawater. Crystallization removes calcium and carbonate ions from the fluid and the reaction proceeds to add new shell layers. However, these reactions are reversible, and under certain conditions, calcium may be removed from the shell, which may explain the deterioration observed in some of the mussel shells. In addition, they suggested that normal calcium metabolism occurs at 10-12 mg/L. Below these levels the mussels lose calcium to the external medium. Presumably, low calcium had an impact on juvenile growth rates because there was not enough calcium provided for shell building.

Financial analysis showed that the initial investment requirement for reconstruction of this abandoned shrimp farm to add a recirculating system with a total culture area of $588 \mathrm{~m}^{2}$ was $\$ 6,371.40$ (USD).

Construction of rearing ponds and the seawater treatment pond was the largest cost component of the farm, representing $77.13 \%$ of the total investment. Operating costs per production cycle were estimated to be $\$ 5,453.50$ (USD). The four major operating cost items were purchasing of juveniles, feed, labor, and electricity. Total cost per production cycle was estimated to be $\$ 6,458.40$ (USD). The top five major cost items were purchasing of juveniles, feed, labor, depreciation, and electricity. The cost of producing spotted babylon to marketable sizes in this farm design was $\$ 7.31 / \mathrm{kg}$ (USD). By contrast, Chaitanawisuti, Kritsanapuntu, and Natsukari (2002) reported that the cost of producing spotted babylon to marketable sizes in the flow-through culture system in Thailand was $\$ 5.96 / \mathrm{kg}$ (USD). For economic analysis, the enterprise budgets, based on the 2007 price of spotted babylon at the farm gate of $\$ 8.57 / \mathrm{kg}$ (USD), resulted in gross returns and net returns per production cycle of $\$ 7,575.90$ (USD) and \$1,117.50 (USD), respectively. The break-even production and break-even price were estimated to be $418.70 \mathrm{~kg}$ and $\$ 3,588.90$ (USD), 
respectively. Benefit cost ratio was 1.17 and payback period was 5.7 production cycles (2.9 years). This study presented a positive net return and a payback period of less than five years, which are often used as business investment criteria.

Under the basic assumptions used in this study [juvenile pricing of $\$ 0.02$ / juvenile (USD), feed pricing of $\$ 0.10 / \mathrm{kg}$ (USD), stocking density of 300 snails / $\mathrm{m}$, and a sale price of $\$ 5.80 / \mathrm{kg}$ (USD)], there is an indication that an operation consisting of the proposed six $4.0 \times 24.5 \times 0.4$ m rearing ponds is economically feasible under these conditions. The feasibility of producing spotted babylon to marketable sizes in this pilot abandoned shrimp farm operation should continue to be examined. Although the return is small, production with $96.8 \%$ survival and selling price of $\$ 5.80$ / $\mathrm{kg}$ (USD) is economically feasible under the assumptions employed. This study provides preliminary evidence for the biological feasibility of culturing the spotted babylon, $B$. areolata, in a large-scale recirculating system. Results of this work showed that juvenile spotted babylon could be successfully grown to marketable size in a recirculating system. In addition, many idled marine shrimp (Penaeus monodon) hatcheries are currently available in Thailand. This study may provide an opportunity to develop a sustainable aquaculture system for grow-out of spotted babylon juveniles to marketable sizes in abandoned marine shrimp hatcheries resulting in the best utilization of the many abandoned shrimp hatcheries in the coastal areas of Thailand. To achieve success, further study should be concentrated on refining farm design to reduce costs, management of seawater treatment, and addressing the problems of slower growth and reduced shell quality due to mineral depletion of the growing water.

\section{ACKNOWLEDGMENTS}

We thank the National Research Council of Thailand (NRCT), who provided funding for this research in fiscal years 2004-2007. I especially wish to express my sincere thanks to Professor Dr. Yutaka Natsukari, Faculty of Fisheries, Nagasaki University, Japan, for his supervision of this research and his revision of this manuscript. 


\section{REFERENCES}

Calta, M. The Effect of Calcium Concentration of Water on Chloride Cell Density in Gill of Brown Trout (Salmo trutta L.) Larvae. Turkish Journal of Biology 2000, 24:331-336.

Chaitanawisuti, N. and Kritsanapuntu, A. Growth and Production of Hatchery-Reared Juvenile Spotted Babylon Babylonia areolata Link, 1807 Cultured to Marketable Sizes in Intensive Flow-Through and Semi-Closed Recirculating Water System. Aquaculture Research 1999, 31:415-419

Chaitanawisuti, N., Kritsanapuntu, S. and Natsukari, Y. Economic Analysis of a Pilot Commercial Production for Spotted Babylon Babylonia areolata Link, 1807 Marketable Sizes Using a Flow-Through Culture System in Thailand. Aquaculture Research 2002a, 33:1-8.

Chaitanawisuti, N., Kritsanapuntu, S. and Natsukari, Y. Effects of Different Types of Substrate on the Growth and Survival of Juvenile Spotted Babylon Babylonia areolata Link, 1807 Reared in a FlowThrough Culture System. Asian Fisheries Science 2002b, 14:279284.

Fuller, M.J., Kelly, R.A., and A.P. Smith. Economic Analysis of Commercial Production of Freshwater Prawn Macrobrachium rosenbergii Postlarvae Using a Recirculating Clearwater Culture System. Journal of Shellfish Research 1992, 11:75-80.

Hincks. S.S. and Mackie, G.L. Effects of pH, Calcium, Alkalinity, Hardness and Chlorophyll on the Survival, Growth, and Reproductive Success of Zebra Mussel (Dreissena polymorpha) in Ontario Lakes. Canadian Journal of Fisheries and Aquatic Sciences 1997, 54:20492057.

Losordo, T.M., Masser, M.P., and Rakocy, J. 1998. Recirculating Aquaculture Tank Production Systems: An Overview of Critical Considerations. Southern Regional Aquaculture Center Publication, SRAC451. 
Masser, M.P., Rakocy, J., and Losordo, T.M. 1999. Recirculating Aquaculture Tank Production Systems: Management of Recirculating Systems. Southern Regional Aquaculture Center Publication, SRAC452.

Rubino, M.C. Economics of Red Claw Cherex quadricarinatus Aquaculture. Journal of Shellfish Research 1992, 11:157-162. 